\title{
Alternatif Pembelajaran Geometri Berbantuan Software GeoGebra di Masa Pandemi Covid-19
}

\author{
Fini Rezy Enabela Novilanti ${ }^{1}$, Suripah ${ }^{2}$ \\ ${ }^{1,2}$ Program Studi Pendidikan Matematika, Universitas Islam Riau (UIR), \\ Jl. Kaharuddin Nst No.113, Perhentian Marpoyan, Riau, Indonesia \\ rezyfini0@gmail.com
}

\begin{abstract}
All learning activities during the Covid-19 pandemic were carried out virtually. This causes a lack of student interest in learning mathematics. Therefore, teachers need to use various ways to understand abstract concepts so that they can be understood by students, namely by utilizing one of the technology-based learning media that can visualize abstract concepts. This study aims to describe students' interest in studying the use of GeoGebra software on geometry material during the Covid-19 pandemic. This research is a descriptive quantitative research. The research sample was students of class VIII which consisted of 18 students who were taken randomly. The instrument used in this study is a non-test instrument in the form of a student interest questionnaire distributed using Google Form, in learning geometry using GeoGebra software which consists of 20 statements as a reference to determine the effectiveness of using GeoGebra software. The data analysis technique used in this research is quantitative descriptive analysis. The results of this study indicate a positive influence on students' interest in learning geometry. As is known, 3 indicators are classified as very good and one indicator is classified as good. GeoGebra software is effectively used as a medium for learning mathematics to attract students' interest in learning.
\end{abstract}

Keywords: geogebra, geometry, interest in learning mathematics, the Covid-19 pandemic

\begin{abstract}
Abstrak
Seluruh kegiatan pembelajaran di masa pandemi Covid-19 dilakukan secara virtual. Hal ini menyebabkan kurangnya minat belajar siswa pada pembelajaran matematika. Oleh karena itu guru perlu menggunakan berbagai cara untuk memahamkan konsep yang abstrak agar dapat dipahami oleh siswa, yaitu dengan memanfaatkan salah satu media pembelajaran berbasis teknologi yang dapat memvisualisasikan konsep yang abstrak. Penelitian ini bertujuan untuk mendeskripsikan minat belajar siswa terhadap penggunaan software GeoGebra pada materi geometri selama masa pandemi Covid-19. Penelitian ini merupakan penelitian kuantitatif deskriptif. Sampel penelitian adalah siswa kelas VIII yang terdiri dari 18 orang siswa yang diambil secara random. Instrumen yang digunakan pada penelitian ini yaitu instrumen non-test berupa angket minat belajar siswa yang disebarkan menggunakan Google Form, pada pembelajaran geometri menggunakan software GeoGebra yang terdiri dari 20 pernyataan sebagai acuan untuk mengetahui efektivitas penggunaan software GeoGebra. Teknik analisis data yang digunakan dalam penelitian ini adalah analisis deskriptif kuantitatif. Hasil penelitian ini menunjukkan adanya pengaruh positif terhadap minat belajar geometri siswa. Seperti diketahui, 3 indikator tergolong sangat baik dan 1 indikator tergolong baik. Software GeoGebra efektif digunakan sebagai media pembelajaran matematika untuk menarik minat belajar siswa.
\end{abstract}

Kata kunci: geogebra, geometri, minat belajar matematika, pandemi Covid-19

Copyright (c) 2021 Fini Rezy Enabela Novilanti, Suripah

$\triangle$ Corresponding author: Fini Rezy Enabela Novilant

Email Address: rezyfini0@gmail.com (Jl. Kaharuddin Nst No.113, Perhentian Marpoyan, Pekanbaru, Indonesia) Received 19 Januari 2021, Accepted 06 Februari 2021, Published 06 Maret 2021

\section{PENDAHULUAN}

Pandemi Covid-19 sudah tidak asing lagi bagi seluruh masyarakat di dunia. Pada tanggal 30 januari 2020 WHO menetapkan sebagai darurat kesehatan berskala global. Hal ini menjadi ancaman kesehatan yang sangat besar bagi masyarakat di dunia. Salah satu negara yang memiliki sistem kesehatan yang rentan adalah negara Republik Indonesia (Sohrabi et al., 2020). 
Indonesia setiap harinya memiliki angka kematian yang cukup tinggi karena pandemi Covid19. Pihak pemerintah Indonesia menginstruksikan masyarakatnya untuk sosial distancing atau physical distancing untuk mengurangi angka kematian dari virus Covid-19. Hal ini berdampak pada seluruh aspek di kehidupan manusia, salah satunya yaitu pada aspek dunia pendidikan. Berdasarkan surat edaran menteri pendidikan dan kebudayaan nomor 4 tahun 2020 tentang pedoman Belajar Dari Rumah (BDR), bahwa seluruh kegiatan proses pembelajaran dialihkan secara daring atau jarak jauh. Hal ini menjadi perubahan secara drastis kegiatan pembelajaran di sekolah, yaitu 1) pembelajaran tatap muka menjadi online; 2) siswa diharuskan belajar mandiri dalam kegiatan pembelajaran; dan 3) seluruh kegiatan pembelajaran menggunakan teknologi (Asyura \& Dewi, 2020).

Guru menggunakan berbagai cara untuk memahamkan konsep yang abstrak agar dapat dipahami oleh para siswa. Namun demikian kondisi pembelajaran yang dilakukan secara virtual pada saat ini menjadi sebuah kendala untuk siswa dalam memahami konsep yang abstrak (Handayani \& Irawan, 2020). Geometri adalah salah satu cabang matematika yang dapat meningkatkan daya pikir kognitif siswa karena dimulai dari fase abstrak hingga akhirnya dapat membentuk konsep dari materi geometri yang diajarkan oleh guru (Al-ebous, 2016). Karena geometri bersifat abstrak dan proses pembelajaran pada saat ini dilakukan secara virtual, menyebabkan siswa sulit untuk memahami materi geometri yang diajarkan oleh guru. Sejalan dengan pendapat Wijaksana \& Rosjanuardi (2021) selama masa pandemi Covid-19 guru tetap mengajarkan materi geometri sesuai dengan kurikulum yang berlaku tetapi perbedaannya terdapat pada proses pembelajaran dilakukan secara virtual. Namun hasil belajar siswa tidak meningkat bahkan turun dari biasanya. Hal ini dapat diketahui sebagai salah satu indikator, bahwa siswa mengalami kesulitan pada materi geometri yang diajarkan.

Hasil penelitian yang dilakukan oleh Azis (2019) dapat diketahui bahwa kesulitan para siswa dalam mempelajari materi geometri khususnya materi bangun ruang sisi datar adalah sulitnya siswa memahami konsep bangun ruang sisi datar seperti pada soal cerita, menentukan rumus yang akan digunakan begitupun dengan operasi hitung nya terkadang siswa keliru dengan hasil yang didapatkan sehingga siswa kurang berminat untuk mempelajari materi yang diajarkan hingga akhir pembelajaran. Sedangkan menurut pendapat Retnawati et al. (2017) kesulitan siswa dalam mempelajari materi geometri bukan hanya pada faktor matematis tetapi berkaitan dengan konsep atau geometri itu sendiri. Aspek lain yang menyebabkan siswa sulit memahami materi geometri terletak pada aspek bahasa, karena sebagian besar guru harus bisa menggunakan bahasa yang mudah dipahami oleh siswa dalam menjelaskan materi geometri yang diajarkan dan menggunakan media yang tepat. Dengan mengatasi permasalahan kesulitan belajar siswa untuk memahami materi geometri, maka siswa akan berminat untuk mengikuti kegiatan pembelajaran sehingga dapat meningkatkan hasil belajar siswa.

Peningkatan hasil belajar siswa dibutuhkan minat belajar yang tinggi dalam proses pembelajaran. Hal ini sependapat dengan (Suripah, 2015) bahwa minat belajar siswa dalam pembelajaran matematika sangatlah penting. Minat belajar berhubungan dengan perasaan netral seseorang atau ditunjukkan melalui ekspresi dan partisipasi siswa. Jika siswa berminat dalam proses 
Alternatif Pembelajaran Geometri Berbantuan Software GeoGebra di Masa Pandemi Covid-19, Fini Rezy Enabela Novilanti, Suripah

pembelajaran maka hasil belajar dan prestasi siswa akan meningkat. Penelitian yang dilakukan oleh Widyastuti et al. (2019) menyimpulkan bahwa siswa tertarik dengan proses pembelajaran. Siswa tidak akan bosan dengan kegiatan pembelajaran matematika, dan respon siswa terhadap kegiatan pembelajaran bersifat positif sehingga hasil belajar siswa akan meningkat. Untuk meningkatkan minat belajar siswa diperlukan suatu media pembelajaran yang dapat menarik minat dan berkaitan dengan materi yang diajarkan.

Salah satu cara untuk menarik minat siswa di masa pandemi Covid-19 adalah dengan menggunakan media pembelajaran. Media pembelajaran yang dapat memajukan ilmu pengetahuan siswa di era globalisasi ini yaitu dengan menggunakan teknologi. Perkembangan teknologi dan ilmu pengetahuan pada saat ini telah mengubah cara pandang dan berfikir secara praktis pada seluruh manusia di dunia (Suripah, 2017). Salah satu dampak teknologi dalam dunia pendidikan pada pembelajaran matematika adalah adanya software matematika, yang dapat digunakan sebagai media pembelajaran di masa pandemi Covid-19. Menurut Rindiantika (2018) media pembelajaran merupakan suatu metode yang digunakan untuk mengirimkan informasi dari pengirim ke penerima yang dapat merangsang pemikiran, perasaan, perhatian dan minat siswa sehingga proses pembelajaran dapat terlaksana dengan optimal. Penelitian yang dilakukan oleh Asyura (2017) menyimpulkan bahwa dengan menggunakan media pembelajaran interaktif dapat meningkatkan minat belajar siswa selama proses pembelajaran.

Salah satu software matematika yang dapat digunakan dalam proses pembelajaran adalah GeoGebra. Cara mendapatkan perangkat lunak GeoGebra sangat sederhana dan dapat diunduh secara gratis dari situs webnya. Sofware GeoGebra merupakan alat inovatif yang terintegrasi teknologi untuk pembelajaran. Karena di dalam software GeoGebra ini terdapat campuran aljabar dan geometri. Selain itu software GeoGebra membuat siswa dapat mengeksplorasi matematika, berpikir kritis dan dapat memudahkan siswa (Bhagat \& Chang, 2015). Sedangkan menurut pendapat Nuraeni et al. (2021) GeoGebra merupakan salah satu software yang dapat mengikuti perkembangan zaman dalam dunia pendidikan. Guru dan siswa dapat menggunakan software GeoGebra untuk mengkontruksi bangun geometri yang terdiri dari titik, vektor, ruas, garis, poligon, irisan kerucut, persamaan, pertidaksamaan, polynomial implisit dan fungsi. Penggunaan software GeoGebra dapat memudahkan pengguna untuk mengkontruksi bangun geometri, sehingga memudahkan dalam memahamkan konsep yang diajarkan.

Dari penelitian yang dilakukan oleh Safitri et al., (2020) bahwa dengan menggunakan software GeoGebra pada materi geometri siswa menjadi lebih aktif, tekun, disiplin dan mudah menjawab soal yang diberikan oleh guru. Sedangkan hasil penelitian yang dilakukan oleh Nuritha \& Tsurayya (2021) menunjukkan bahwa dengan bantuan software GeoGebra pada kegiatan pembelajaran dapat meningkatkan kemandirian siswa dalam proses pembelajaran sehingga software GeoGebra efektif digunakan dalam kegiatan pembelajaran selama masa pandemi Covid-19. Adapun fungsi software GeoGebra menurut Akhirni \& Mahmudi (2015) adalah software GeoGebra dalam kegiatan 
pembelajaran dapat menyajikan materi pembelajaran menjadi menarik, mempermudah siswa dalam mengkontruksikan bangun geometri, dan mempermudah siswa dalam menyelesaikan soal-soal matematika yang diberikan oleh guru. Sebagai dampaknya siswa menjadi termotivasi dan menarik minat siswa dalam proses pembelajaran.

Berdasarkan hasil beberapa penelitian yang telah dijabarkan, maka peneliti melakukan analisis terhadap penggunaan software GeoGebra pada materi geometri yang ditinjau dari aspek minat belajar siswa selama masa pandemi Covid-19. Tujuan dari penelitian ini untuk mendeskripsikan minat belajar siswa terhadap penggunaan software GeoGebra pada materi geometri selama masa pandemi Covid19.

\section{METODE}

Penelitian ini merupakan penelitian kuantitatif yang dilakukan dengan menggunakan metode deskripsi kuantitatif. Penelitian ini bertujuan untuk mendeskripsikan respon minat belajar siswa terhadap penggunaan software GeoGebra sebagai alternatif pembelajaran geometri di masa pandemi Covid-19 secara deskriptif kuantitatif. Respon minat belajar siswa di deskripsikan dengan cara menghitung angket respon minat belajar siswa. Adapun respon minat belajar siswa terhadap pembelajaran geometri berbantuan software GeoGebra ditentukan dengan cara mengkonversikaan data angket respon minat belajar siswa kedalam data kuantitatif. Subjek penelitian sebanyak 18 orang siswa kelas VIII yang diambil secara random. Pada penelitian ini siswa mengamati video pembelajaran berbantuan software GeoGebra pada materi geometri.

Penelitian ini menggunakan instrumen non-test berupa angket minat belajar siswa. Sebelum diberikan angket respon minat belajar siswa terlebih dahulu peneliti melakukan validasi isi terhadap standar kurikulum matematika SMP kelas VIII. Validasi ini dimaksud untuk melihat kesesuaian materi dengan media pembelajaran yang diberikan kepada siswa berbantuan software GeoGebra. Tahap selanjutnya perangkat yang telah disusun dikonsultasikan kepada ahli dalam hal ini adalah dosen pendidikan matematika sebanyak 2 orang. Berdasarkan masukan yang diberikan, peneliti memperbaiki media sesuai dengan saran dan masukan sampai media yang dibuat oleh peneliti dinyatakan valid. Sedangkan instrument berupa angket respon minat belajar siswa dikonstruk berdasarkan indikator-indikator minat belajar sesuai kajian teori untuk membuat butir-butir pernyataan angket minat belajar siswa. Butir -butir yang telah dikonstruk selanjutnya divalidasi kepada ahli dengan merevisi masukan-masukan dari ahli hingga dinyatakan angket minat belajar valid.

Pada angket minat belajar siswa, peneliti memodifikasi empat indikator minat belajar siswa dari Syahputra (2020) yaitu: (1) Perasaan senang; (2) Ketertarikan siswa; (3) Perhatian siswa; dan (4) Keterlibatan siswa, yang setiap indikator memiliki 5 pertanyaan, sehingga jumlah seluruh angket minat belajar siswa adalah 20 pernyataan, yang masing-masing terdiri dari 15 pernyataan positif dan 5 pernyataan negatif yang disebarkan menggunakan Google Form. Kategori skala minat belajar 
pernyataan positif yang digunakan dalam angket merupakan modifikasi dari skala likert, dan bentuk kategorinya terdiri dari empat pilihan, yaitu sangat setuju (4), setuju (3), dan tidak setuju (2), sangat tidak setuju ( 1). Sedangkan pada item skala minat pernyataan negatif yang digunakan sebaliknya dari skor penilaian pernyataan positif.

Teknik analisis data yang digunakan pada penelitian ini yaitu deskriptif kuantitatif dengan berbantuan Microsoft Excel. Pengolahan data dilakukan dengan cara menghitung persentase masingmasing indikator minat belajar siswa yang terdiri dari perasaan senang, ketertarikan siswa, perhatian siswa, dan keterlibatan siswa. Setelah mendapatkan hasil dari analisis data, selanjutnya mengkategorikan angket minat belajar siswa sesuai tabel di bawah ini.

Tabel 1. Kriteria skor penilaian angket

\begin{tabular}{|c|c|c|}
\hline No & Interval (\%) & Kriteria \\
\hline 1 & $81-100$ & Sangat Baik \\
\hline 2 & $68-80$ & Baik \\
\hline 3 & $41-60$ & Cukuo \\
\hline 4 & $21-40$ & Kurang \\
\hline 5 & $0-20$ & Kurang Sekali \\
\hline
\end{tabular}

Sumber: (Arikunto, 2010)

\section{HASIL DAN DISKUSI}

Karena pembelajaran dilaksanakan secara daring maka penelitian dilaksanakan dengan menggunakan video pembelajaran yang berisi materi geometri dengan menggunakan software GeoGebra. Berikut adalah cuplikan materi geometri yang ditampilkan menggunakan video pembelajaran.

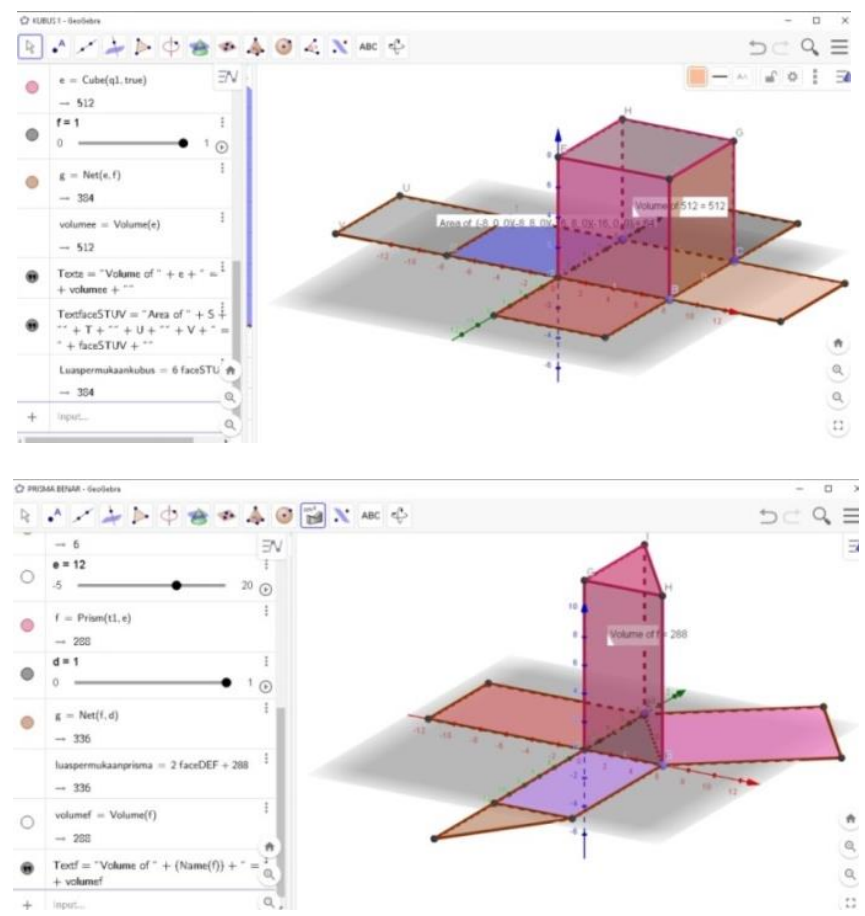

Gambar 1. Cuplikan materi 
Setelah siswa menonton video pembelajaran yang diberikan selanjutnya siswa mengisi angket minat belajar yang terdiri dari 4 indikator. Berikut adalah hasil penelitian dari instrument non-test yang telah diisi oleh siswa:

1. Hasil persentase tanggapan siswa terhadap perasaan senang sebagaimana disajikan pada Gambar

2

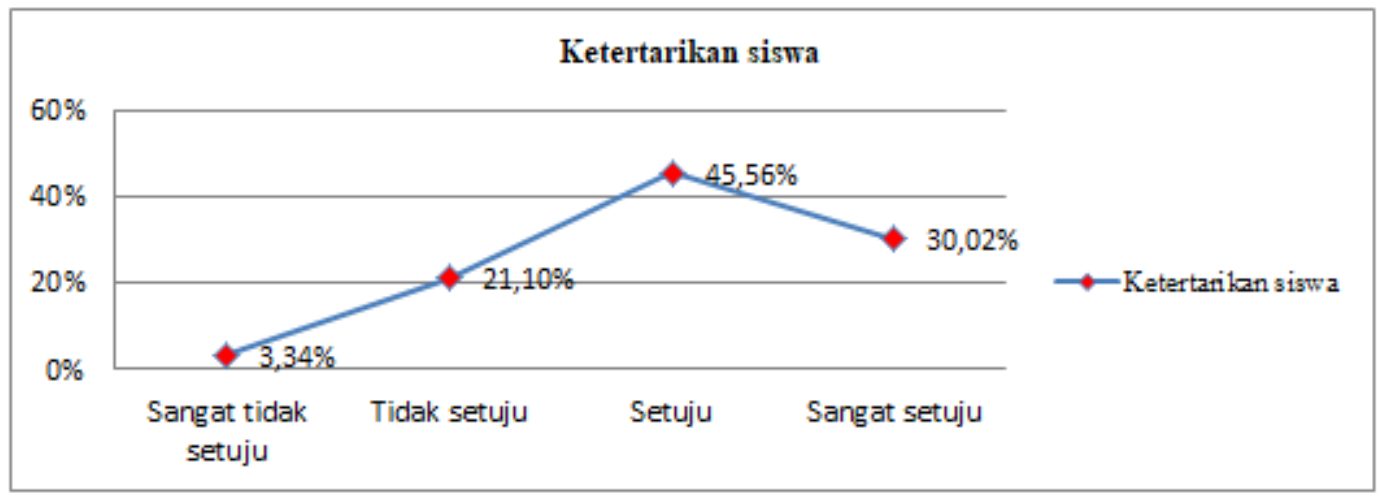

Gambar 2. Persentase respon siswa pada indikator perasaan senang

Dari gambar 2 terlihat bahwa 39,98\% siswa sangat setuju ketika guru menggunakan software GeoGebra siswa merasa senang dan dapat mempermudah siswa untuk memahami materi geometri dengan baik. Sementara terdapat 56,68 \% siswa setuju bahwa software GeoGebra dapat menjadikan siswa bersemangat dalam proses pembelajaran sehingga siswa berminat mengikuti proses pembelajaran hingga akhir dan terdapat 3,34\% siswa mengalami kesulitan untuk menggunakan software GeoGebra. Dari persentase tersebut dapat diketahui pada indikator perasaan senang memiliki kategori sangat baik.

2. Hasil persentase tanggapan siswa terhadap indikator ketertarikan siswa sebagaimana disajikan pada Gambar 3

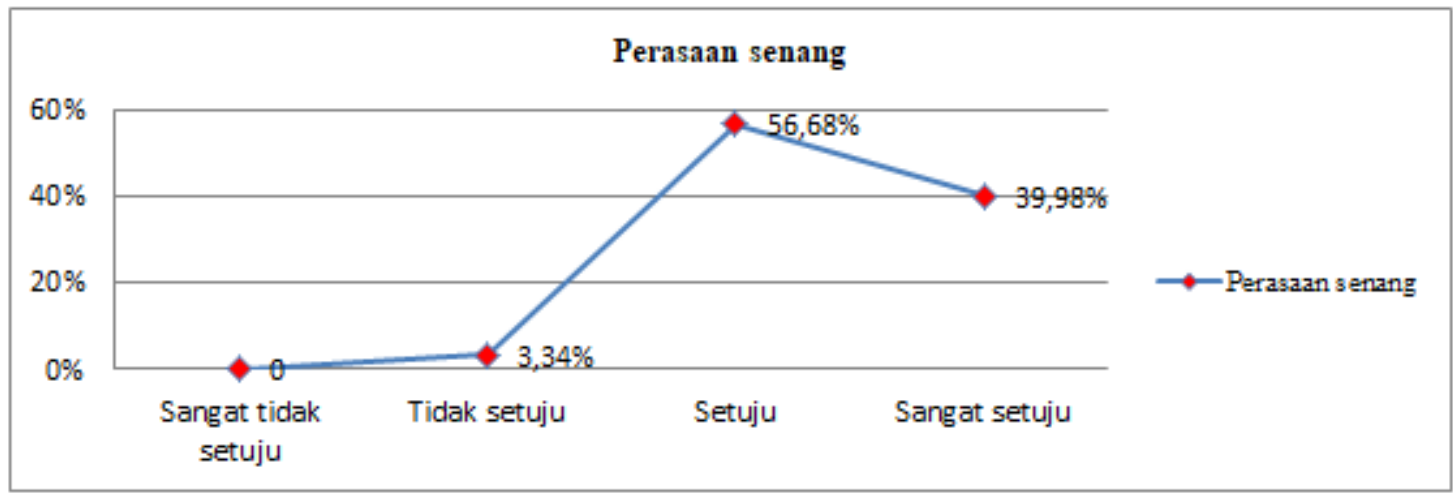

Gambar 3. Persentase respon siswa pada indikator ketertarikan siswa

Berdasarkan gambar 3 menunjukkan bahwa sebanyak 30,02\% siswa sangat setuju bahwa dengan menggunakan software GeoGebra siswa tidak merasa bosan pada proses pembelajaran dan tertarik untuk mengetahui informasi lebih lanjut tentang penggunaan software GeoGebra. Terdapat 45,56\% siswa setuju ketika guru menjelaskan penggunaan software GeoGebra siswa mencatat poinpoin penting tentang cara menggunakan ikon pada software GeoGebra dan siswa langsung tertarik 
Alternatif Pembelajaran Geometri Berbantuan Software GeoGebra di Masa Pandemi Covid-19, Fini Rezy Enabela Novilanti, Suripah

untuk mencoba menggunakan software GeoGebra pada materi geometri. Untuk respon siswa tidak setuju dan sangat tidak setuju terdapat $21,10 \%$ dan $3,34 \%$, siswa yang masih bingung tentang kegunaan ikon-ikon pada software GeoGebra sehingga siswa kurang tertarik untuk mengetahui lebih lanjut tentang software GeoGebra. Dari persentase respon siswa pada indikator ketertarikan siswa terhadap software GeoGebra tergolong baik.

3. Hasil persentase tanggapan siswa terhadap indikator perhatian siswa sebagaimana disajikan pada Gambar 4

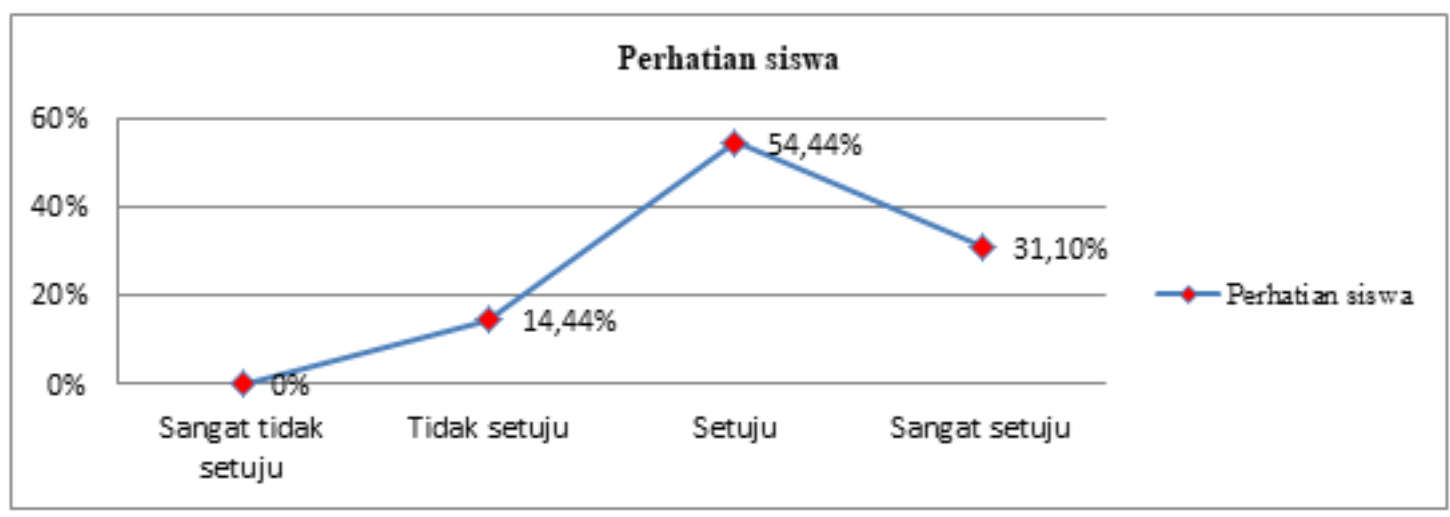

Gambar 4. Persentase respon siswa pada indikator perhatian siswa

Hasil persentase respon siswa pada indikator perhatian siswa terhadap penggunaan software GeoGebra terdapat $31,10 \%$ siswa sangat setuju bahwa selama proses pembelajaran dengan menggunakan software GeoGebra siswa memperhatikan guru, tentang bagaimana cara mendapatkan luas permukaan dan volume dari materi geometri yang diajarkan. 54,44\% respon siswa setuju bahwa selama proses pembelajaran hingga akhir siswa memperhatikan guru tentang langkah-langkah menggunakan software GeoGebra. Sementara terdapat $14,44 \%$ respon siswa tidak setuju memperhatikan guru hingga akhir proses pembelajaran sehingga siswa tidak memperhatikan setiap langkah penggunaan software GeoGebra. Pada indikator perhatian siswa tergolong dalam kategori sangat baik.

4. Hasil persentase tanggapan siswa terhadap indikator keterlibatan siswa sebagaimana disajikan pada Gambar 5

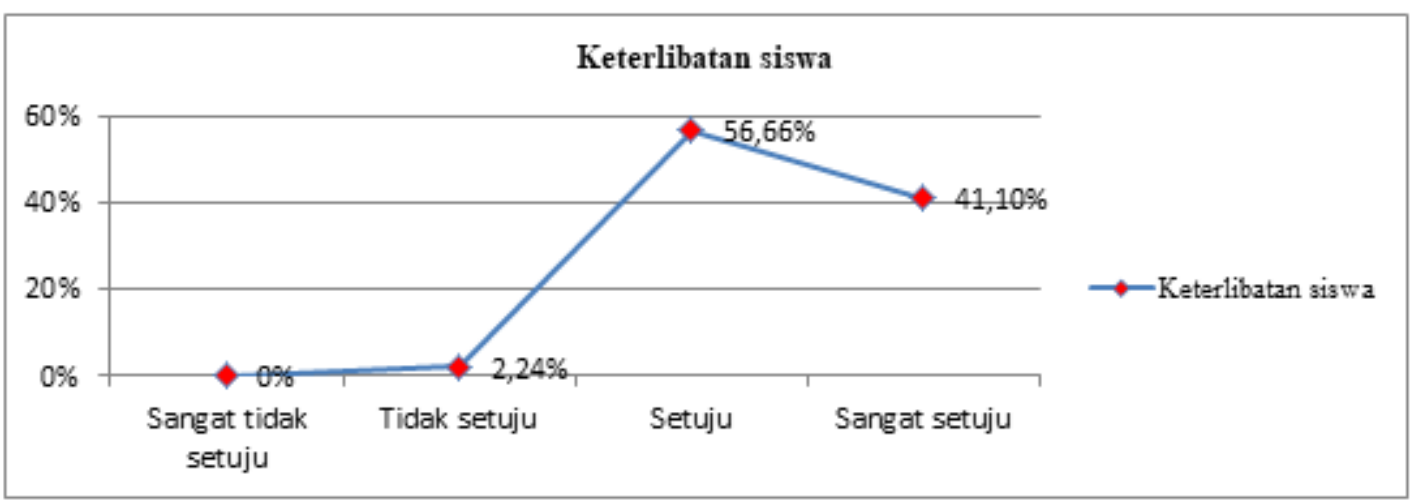

Gambar 5. Persentase respon siswa pada indikator keterlibatan siswa 
Pada indikator keterlibatan siswa yang terdapat pada gambar 5 terdapat 41,10\% siswa sangat setuju bahwa soal yang guru berikan bisa siswa kerjakan dan ketika siswa belum paham terhadap materi yang disampaikan oleh guru, siswa akan bertanya kepada guru. Sebanyak 56,66\% respon siswa setuju bahwa dengan menggunakan software GeoGebra siswa lebih mudah menyelesaikan soal yang diberikan sehingga siswa akan menggunakan software GeoGebra pada materi matematika lainnya. Sementara terdapat 2,24\% siswa yang masih malu untuk bertanya ke guru terhadap materi yang belum dipahami. Pada indikator keterlibatan siswa terhadap software GeoGebra masih tergolong pada kategori sangat baik.

Media pembelajaran memegang peranan yang sangat penting dalam proses pembelajaran, melalui penggunaan media pembelajaran siswa akan lebih tertarik untuk belajar hingga akhir proses pembelajaran. Hal ini didukung oleh penelitian yang dilakukan oleh Borovcnik \& Kapadia (2009) penelitian tersebut menyimpulkan bahwa dengan menggunakan media pembelajaran yang disesuaikan dengan era globalisasi, siswa akan menghadapi tantangan yang lebih besar untuk memecahkan masalah yang mereka hadapi, dan dapat membantu siswa dalam memberikan kegiatan pembelajaran. pengalaman baru.

Software GeoGebra adalah salah satu media pembelajaran yang dapat digunakan dalam proses pembelajaran pada era saat ini. Karena software GeoGebra ketika digunakan tidak membutuhkan internet, sehingga mudah digunakan oleh guru maupun siswa. Hal ini sependapat dengan Nopiyani et al. (2016) bahwa software GeoGebra cocok digunakan oleh negara indonesia atau negara berkembang, karena pada software GeoGebra terdapat pilihan bahasa dan mudah diunduh oleh pengguna. Selain mudah diunduh dan mudah digunakan software GeoGebra dapat mensimulasikan permasalahan yang diberikan oleh guru dengan jelas sehingga siswa dapat memahami permasalahan yang diberikan (Amalia et al., 2020). Hal ini sejalan dengan hasil penelitian yang dilakukan oleh $\mathrm{Bu}$ \& Haciomeroglu (2010) software GeoGebra tidak asing lagi di telinga para pendidik maupun calon pendidik. Karena software GeoGebra mudah digunakan dari pada software matematika lainnya, khususnya pada materi geometri.

Berdasarkan data hasil penelitian yang telah dijabarkan bahwa setiap indikator minat belajar siswa yang terdapat pada angket tergolong sangat baik Hal ini menunjukkan respon positif siswa terhadap penggunaan software GeoGebra pada materi geometri. Hal ini sejalan dengan hasil penelitian yang dilakukan oleh Nurhayati et al. (2019) \& Zetriuslita et al.(2020) bahwa dengan menggunakan media pembelajaran berupa aplikasi GeoGebra pada saat proses pembelajaran sebagian besar siswa memiliki minat belajar yang bagus. Siswa menjadi lebih bersemangat untuk memecahkan permasalahan yang diberikan oleh guru. Dengan kata lain, pemanfaatan software GeoGebra dalam proses pembelajaran khususnya pada materi geometri dapat meningkatkan minat belajar siswa.

\section{KESIMPULAN}

Pembelajaran matematika hendaknya tidak terfokus hanya pada materinya saja tetapi juga harus 
Alternatif Pembelajaran Geometri Berbantuan Software GeoGebra di Masa Pandemi Covid-19, Fini Rezy Enabela Novilanti, Suripah

memperhatikan strategi dan menggunakan media pembelajaran yang bervariasi yang dapat menarik minat belajar siswa pada proses pembelajaran. Hasil penelitian ini menunjukkan bahwa dengan menerapkan software GeoGebra dalam proses pembelajaran dapat menarik minat belajar siswa dalam proses pembelajaran. Selama proses pembelajaran terjadi, siswa memberikan respon yang sangat baik terhadap penggunaan software GeoGebra. Dengan demikian, dengan memanfaatkan software GeoGebra dalam proses pembelajaran dapat memberikan dampak yang positif dan meningkatkan minat belajar siswa di masa pandemi Covid-19.

Pada penelitian selanjutnya hendaknya, perlu dikaji penggunaan software GeoGebra terhadap hasil belajar siswa pada materi matematika yang lainnya. Hal ini dimaksud agar software GeoGebra bukan hanya dapat diketahui pada materi geometri, tetapi juga dapat pada materi matematika yang lainnya.

\section{UCAPAN TERIMA KASIH}

Ucapan terimakasih kepada ibu Dr. Suripah, M. Pd selaku dosen pembimbing dan Program Studi Pendidikan Matematika Universitas Islam Riau, kemudian terimakasih kepada para siswa yang telah berpartisipasi dalam pengisian angket penelitian ini dan kepada pihak-pihak yang telah membantu dalam menyelesaikan penelitian ini.

\section{REFERENSI}

Akhirni, A., \& Mahmudi, A. (2015). Pengaruh Pemanfaatan Cabri 3D dan GeoGebra pada Pembelajaran Geometri Ditinjau dari Hasil Belajar dan Motivasi. Jurnal Pendidikan Matematika Dan Sains Tahun III, 3(2), 91-100. https://doi.org/10.21831/jpms.v6i2.10922

Al-ebous, T. (2016). Effect of the Van Hiele Model in Geometric Concepts Acquisition: the Attitudes Towards Geometry and Learning Transfer Effect of the First Three Grades Students in Jordan. International Education Studies, 9(4), 87. https://doi.org/10.5539/ies.v9n4p87

Amalia, S. R., Purwaningsih, D., Widodo, A. N. A., \& Fasha, E. (2020). Model Problem Based Learning Berbantuan GeoGebra dan Model Realistic Mathematics Education Terhadap Representasi Matematis Siswa Ditinjau dari Gaya Kognitif. Jurnal Elemen, 6(2), 157-166. https://doi.org/10.29408/jel.v6i2.1692

Arikunto, S. (2010). Manajemen Penelitian. Jakarta: Rineka Cipta.

Asyura, I ra. (2017). Pengembangan Media Pembelajaran Interaktif Berbasis Kontruktivisme pada Materi Prisma dan Limas di Kelas VIII SMP Ira Asyura. Cakrawala Pedagogik, 1(2), 214-228. https://doi.org/10.17605/OSF.IO/Z4B93

Asyura, Ira, \& Dewi, R. (2020). Analisis Kemampuan Matematis Mahasiswa PGSD Terhadap Penggunaan GeoGebra Classroom di Era dan Pasca Pandemi Covid-19. Jurnal Pendidikan Matematika, 04(02), 976-989.

Azis. (2019). Analisis Kesulitan Siswa dalam Menyelesaikan Soal Cerita pada Pembelajaran Matematika Kelas VIII. Jurnal Akademik Pendidikan Matematika, 5, 64-72.

Bhagat, K. K., \& Chang, C. (2015). Incorporating GeoGebra into Geometry learning-A lesson from 
India. 11(1), 77-86. https://doi.org/10.12973/eurasia.2015.1307a

Borovcnik, M., \& Kapadia, R. (2009). Reserch and Development in Probability Education. International Electronic Journal of Mathematics Education, 4(3), 111-130. https://doi.org/10.1021/ed085p1019

Bu, L., \& Haciomeroglu, S. (2010). GeoGebra in Mathematics Teacher Education: the Case of Quadratic Relations. MSOR Connections, 10(1), 6-9. https://doi.org/10.11120/msor.2010.10010006

Handayani, S. D., \& Irawan, A. (2020). Pembelajaran Matematika di Masa Pandemi Covid-19 Berdasarkan Pendekatan Matematika Realistik. Jurnal Math Educator Nusantara, 6(2), 179189. https://doi.org/10.29407/jmen.v6i2.14813

Nopiyani, D., Prabawanto, S., \& Turmudi. (2016). Penerapan Pembelajaran Matematika Realistik Berbantuan GeoGebra Untuk Meningkatkan Kemampuan Komunikasi Matematis Siswa SMP. Jurnal Pendidikan Matematika STKIP Garut, 5(2), 45-52.

Nuraeni, Z., Indaryanti, \& Sukmaningthias, N. (2021). Pengembangan Perangkat Pembelajaran Bercirikan CTL Berbantuan GeoGebra Menggunakan Model Flipped Learning. Jurnal Elemen, 7(1), 58-69. https://doi.org/10.29408/jel.v7i1.2723

Nurhayati, L., Setiawan, W., \& Matematika, P. (2019). Analisis Minat Belajar Matematika Siswa SMA pada Materi Program Linier Berbantuan Aplikasi GeoGebra. Journal on Education, 02(01), 1-8.

Nuritha, C., \& Tsurayya, A. (2021). Pengembangan Video Pembelajaran Berbantuan Geogebra untuk Meningkatkan Kemandirian Belajar Siswa. Jurnal Cendekia: Jurnal Pendidikan Matematika, 05(01), 48-64.

Retnawati, H., Arlinwibowo, J., \& Sulistyaningsih, E. (2017). The Students' Difficulties in Completing Geometry Items of National Examination. International Journal on New Trends in Education and Their Implications (IJONTE), 8(4), 28-41.

Rindiantika, Y. (2018). Penerapan Media dalam Kegiatan Pembelajaran Bahasa Inggris:Kajian Teoritik. Jurnal Intelegensi, 3(April), 1-13.

Safitri, S., Nursyamsiah, G., Setiawan, W., \& Belakang, L. (2020). Analisis Minat Belajar Siswa MTs dalam Pembelajaran Matematika Berbantuan GeoGebra. Maju, 7(1), 111-116.

Sohrabi, C., Alsafi, Z., Neill, N. O., Khan, M., \& Kerwan, A. (2020). World Health Organization Declares Global Emergency: A Review of The 2019 Novel Coronavirus (COVID-19). International Journal Of Surgery, January, 71-76.

Surat Edaran Nomor 4 tentang Pelaksanaan Pendidikan dalam Masa Darurat Corona Virus (COVID-19). (2020). Jakarta: Kemdikbud.

Suripah. (2015). Komparasi Keefektifan Model Pembelajaran Kooperatif Tipe Student Teams Achievement Divisions (STAD) dan Tipe Think Pair Share (TPS) pada Siswa SMP. Jurnal Pengajaran Matematika Dan Ilmu Pengetahuan Alam, 6(1), 125. https://doi.org/10.18269/jpmipa.v20i2.575

Suripah. (2017). Mengembangkan Keterampilan Mengajar Berbasis ICT Bagi Calon Guru Abad XXI. Prosiding KMP Education Research Conference, 676-684. Yogyakarta: MIPA UNY. 
Alternatif Pembelajaran Geometri Berbantuan Software GeoGebra di Masa Pandemi Covid-19, Fini Rezy Enabela

Syahputra, E. (2020). Snowball Throwing Tingkatkan Minat dan Hasil Belajar. Sukabumi: Haura Publishing.

Widyastuti, Wijaya, A. P., Rumite, W., \& Marpaung, R. R. T. (2019). Minat Siswa Terhadap Matematika dan Hubungannya dengan Metode Pembelajaran dan Efikasi Diri. Jurnal Pendidikan Matematika, 13(1), 83-100. https://doi.org/10.22342/jpm.13.1.6750.83-100

Wijaksana, A. H., \& Rosjanuardi, R. (2021). Kesalahan Konsep Descriptive Geometry Mahasiswa Terhadap Kemampuan Spasial dalam Pembelajaran Daring di Masa Pandemi Covid-19. Jurnal Elemen, 7(1), 180-194. https://doi.org/10.29408/jel.v7i1.2967

Zetriuslita, Z., Nofriyandi, N., \& Istikomah, E. (2020). The Effect of Geogebra-ssisted Direct Instruction on Students' Self-efficacy and Self-regulation. Infinity Journal, 9(1), 41. https://doi.org/10.22460/infinity.v9i1.p41-48 